International Journal of Instruction e-ISSN: 1308-1470 • www.e-iji.net

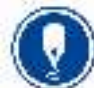

April 2021 • Vol.14, No.2

p-ISSN: 1694-609X

pp. $217-232$

Article submission code

20200219060639

Received: 19/02/2020

Revision: 06/09/2020
Accepted: 30/09/2020

OnlineFirst: 16/01/2021

\title{
Problem-Based Learning with Character-Emphasis and Naturalist Intelligence: Examining Students Critical Thinking and Curiosity
}

\section{Suhirman}

Universitas Islam Negeri Mataram, Indonesia, suhirman@uinmataram.ac.id

\section{Saiful Prayogi}

Universitas Pendidikan Mandalika, Indonesia, saifulprayogi@ikipmataram.ac.id

\section{Muhammad Asy'ari}

Universitas Pendidikan Mandalika, Indonesia, muhammadasyari@ikipmataram.ac.id

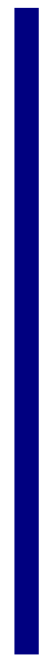

\begin{abstract}
This research aimed to examine the effects of problem-based learning with character emphasis and naturalist intelligence on the students' critical thinking skills and curiosity. This study was conducted at Islamic Senior High School in Mataram and it employed $3 \times 2$ treatment by level design. Three treatments; the problem-based learning with character emphasis (PBL-CE) (A1), the problembased learning (PBL) (A2), and the regular learning (RL) (A3) were given to two groups; the students with high naturalist intelligence (B1) and low naturalist intelligence (B2). The data on the students' naturalist intelligence and critical thinking were collected through the test and the data on the students' curiosity was collected through self-assessment and observation sheets. The data were analyzed using MANOVA at 0,05 significance level. The results of the study showed that: (1) the PBL-CE affect the students critical thinking skills and curiosity, (2) the naturalist intelligence does not have a significant effect on the students critical thinking skills and students curiosity, and (3) the interaction between the PBL-CE and naturalist intelligence did not affect the students critical thinking skills and curiosity. PBL-CE can be applied as alternative learning to develop students' critical thinking and curiosity.
\end{abstract}

Keywords: problem-based learning, character emphasis, naturalist intelligence, critical thinking, curiosity

\section{INTRODUCTION}

Learning does not only focus on academic performance but also develops and increases the capacity of students as a whole (Mak, 2014). Education must be managed so that it can produce thinking resources capable of building a knowledge-based social and economic order in the 21st century (Elmuhtarim, 2018; Patel et al., 2017), industry 4.0 (Schwab, 2016), and society 5.0 (Skobelev \& Borovik, 2017). Students must be trained

Citation: Suhirman., Prayogi, S., \& Asy'ari, M. (2021). Problem-Based Learning with CharacterEmphasis and Naturalist Intelligence: Examining Students Critical Thinking and Curiosity. International Journal of Instruction, 14(2), 217-232. https://doi.org/10.29333/iji.2021.14213a 
to use the power of arguments, thinking skills, and morals or characters in education. Students' capacity including skills, work habits, and characters that are believed to be essential to achieve a successful life (Anazifa \& Djukri, 2017). They will face rapid and arduous changes in science and technology (Ritter \& Mostert, 2016; Mapeala \& Siew, 2015; Rehmat \& Bailey, 2014). In brief, critical thinking skills, characters, and curiosity are three pivotal capital for students to face the world changes which must be developed simultaneously in education.

Critical thinking skills are an important aspect of modern education (Mouhtarim, 2018; Walter \& Walter, 2018), important competencies in the successful performance of students (Verawati et al., 2019a, 2019b; Hasanpour et al., 2018; Prayogi et al., 2017), and the most important real-life skills (Mutakinati \& Anwari, 2018). It is an essential ability that must be possessed by students in solving problems (Handoyo et al., 2019; Özgenel, 2018) and a process to make sound decisions (Özgenel, 2018) so that what we think is best about a truth we can do right. Critical thinking helps the student to define the cause of a change in a variable and the effect of one variable on other variables (Duran \& Dökme, 2016). The essential things in critical thinking are practical, reflective, reasonable (Handoyo et al., 2019; Mutakinati \& Anwari, 2018), beliefs, and actions. From this combination of five basic components, critical thinking is defined as reflective thinking that focuses on deciding what to believed to do.

In the learning of science, students' critical thinking can be seen from the ability of students to respond to every problem about everyday life. Critical students tend to be more active in trying to solve problems (Handoyo et al., 2019), self-corrective thinking (Mutakinati \& Anwari, 2018), and can better recognize and regulate their emotions (Yao et al., 2018). They actively clarify a problem by asking, looking at a problem from a different side, digging up important information related to the problem to be solved, daring to express their opinions and ideas to criticize solutions that he thinks are rational, and able to draw conclusions from solving existing problems.

Curiosity is one of the educational aspects that must be developed in learning. Curiosity is defined as a willingness to explore something that is unknown, meet new things, and accept uncertainty (Arnone et al., 2011). It is a personality (Kaczmarek et al., 2014), an integral aspect of science learning (Weible \& Zimmerman, 2016), and the importance that an individual should have as a requirement of learning (Gulten et al., 2011). Students who have high curiosity are indicated by; enthusiastic to seek answers each question, attention to the observed object, enthusiastic on the science process, and put on every step of the activity (Nasution et al., 2018).

Prior studies indicate that the students' critical thinking skills are not satisfactory. Critical thinking skills are still low (Khasani et al., 2019). Previous studies (Latifa et al., 2017; Qing et al., 2010; Miri et al., 2007) report that the students critical thinking skill is the lowest secondary school. The learning process that has been going on so far has not been able to improve critical thinking because cognitive aspects are only emphasized on results not on aspects of processes that involve critical thinking skills. In addition, the learning model applied by the teacher does not lead to the achievement of critical thinking skills. Practicing critical thinking requires a holistic approach using appropriate 
teaching modes that allow students to manipulate their cognitive processes to stimulate their critical thinking skills (Prayogi et al., 2018; Prayogi et al., 2019; Wahyudi et al., 2018, 2019a, 2019b). The students curiosity in learning is also far from expectation. Ciptasari et al (2015) found that the students' curiosity is in a low category. Students' activity such as questioning or reading several relevant sources did not significantly increase in learning (Nasution et al., 2018). Therefore, it is necessary to make a serious effort by creating appropriate learning strategies for the continuous development of the students' critical thinking skills and the students' curiosity.

Learning strategy is one of the external factors which affect the students' critical thinking skills and curiosity. Besides that, there are also internal factors, one of which is naturalist intelligence. Naturalist intelligences is defined as the potential to process information that is exhibited by naturalists (Hayes, 2009). Gardener (1999) believes that naturalist intelligences as firmly entrenched as the other intelligences. The development of naturalist intelligence in children requires the right environment to be nurtured, because naturalist intelligence is literally related to the environment (Barbiero \& Berto, 2018). To be able to develop optimally the naturalist intelligence of the child, it is necessary to have stimulation in children (Hasanah et al., 2019). Essentially, naturalist intelligence is a part of multiple intelligences possessed by humans. It involves sensitivity to problems or natural phenomena and the ability to distinguish between living and non-living things or beings (Rohmah, 2016). Characteristics that can be seen when children have naturalist intelligence include the ability of children to attract natural world, children's ability to mark similarities and differences around them, children's ability to mark patterns and natural objects, and children's interest in stories related to phenomena nature, and children like to pay attention to the nature around them. These characteristics continue to develop in children with increasing age (Hasanah et al., 2019). According to Roos (2017), students with high naturalist intelligence have a strong affinity for nature. Strong affinity is indicated by great interest in learning the topics related to nature and its phenomena.

Classroom instruction is one of the efforts to develop the students' critical thinking skills and students' curiosity. Ideally, it ought to be designed to improve the students' academic performance as well as increase the students' curiosity. The learning models should be enriched with character education to helps schools develop students' morality (Dinkha, 2008). The instructional design which embeds character is important to make sure that the learning is also focused on character building, not a mere achievement of academic results. Designing and intervening in instruction systematically for creating a learning environment needs to be carried out and its effectiveness needs to be investigated in developing the students thinking skills (Tiruneh et al., 2018; Delaney et al., 2017).

In the current research, the intervention in learning is the addition of character content to the syntax of problem-based learning which is later known as problem-based learning with character emphasis (PBL-CE). PBL-CE is a kind of PBL strategy designed by sharpening stages of the learning activities in order to strengthen the students' character and diversifying the syntax of PBL in terms of meaning in order to establish the 
students' character. Thus, the stages of the learning in PBL-CE are enriched with activities that encourage the students to the practice of forming characters consciously or unconsciously, without ignoring the meaning in the syntax of PBL itself.

Existing research applying PBL integrated with multimedia, and its significantly influences the students' critical thinking ability (Susilawati et al., 2018). However, practicing critical thinking with multimedia including virtual laboratories still does not expose learners to real-world situations, because the process of training critical thinking will be better when there is conduction between the topic being studied with the realworld context (Hofstein et al., 2001), so the virtual laboratory (virtual fields) cannot replace real laboratories (Cassady et al., 2008). Complex, contextual, and structural problems provide the students with an opportunity to develop their ability to think analytically, evaluatively, and reflectively and develop their creativity in exploring various information, develop various possible solutions, and create various sources to solve the problems faced (Tsai \& Chiang, 2013). PBL increases the students' selfconfidence, creates a supportive environment which leads to teamwork, enhances interpersonal communication and critical thinking skills, and build self-awareness (Moody et al., 2018; Aldarmahi, 2016). According to Aldarmahi (2016), PBL is useful for students in constructing knowledge, developing reasoning processes, improving independent learning skills, and increasing intrinsic learning motivation. This research seeks to find out the effect of PBL-CE and naturalist intelligence on the students critical thinking skills and curiosity.

\section{Problem of Research}

Facing the 21st century, education in Indonesia must be oriented to mathematics and science accompanied by social and human sciences (BSNP, 2010). Human resources needed are those who have the ability to think critically and solve problems (Eichmann et al., 2019; Osman, 2010; Oktay \& Safak, 2012) and the ability to create and renew (Ertmer et al., 2014). The fact that occurs in Indonesian secondary schools, critical thinking skills has not become a serious concern in learning. The teachers' do not consciously plan and carry out learning which only emphasizes low-level thinking skills.

Education is not merely a function of transferring knowledge, but also as a driver for the development of noble values which are the basis for the development of good morals (Callina et al., 2018; Isdaryanti et al., 2018; Muliastuti, 2017). Good morals include curiosity. Therefore, schools must encourage students to be able to understand good moral values, have moral feelings, and finally have a strong commitment to carry out what they know and feel in moral action. In fact the cultivation of noble values, such as curiosity is still not running optimally. The science teacher considers that the inculcation of character is mostly done by the teachers who teach the religious subject. In addition, an assessment of students curiosity aspects is carried out by the teacher in order to complete the teaching administration when supervising learning by the school principal.

Constructivism learning activities include observing phenomena, collecting data, formulating and testing hypotheses, through collaboration with others. This is in accordance with the nature of science which includes the scientific attitude of science, 
scientific processes, and scientific products. The scientific attitude of science is related to curiosity, humility, openness, honesty, positive models of failure, and responsibility. The science process is related to thinking skills, which is the process carried out by scientists through scientific methods. Science products include scientific concepts, principles, and theories. But the reality is that the teacher of secondary schools in Indonesia is still dominant in implementing regular learning and the learning process is more dominated by the teacher. In fact, the regular learning model has not been able to develop students' critical thinking skills and has not been able to accustom students' attitudes of curiosity.

\section{Research Focus}

This research focused on the effect of the PBL-CE on the students' critical thinking skills and curiosity, the effect of the naturalist intelligence on the students' critical thinking skills and curiosity, and the effect of the interaction between the PBL-CE and naturalist intelligence on the students critical thinking skills and curiosity.

\section{METHODS}

This was a quasi-experimental study conducted at secondary schools in Mataram Indonesia, using treatment by level $3 \times 2$ design. Three kinds of treatments namely the PBL-CE (A1), the PBL (A2), and the RL (A3), were given to both the students with high naturalist intelligence (B1) and the students with low naturalist intelligence (B2) during the learning.

The PBL-CE group is given PBL which is enriched by teacher activities that encourage the strengthening of student character. PBL groups are given learning with PBL strategies only. The RL group received learning as planned by the teacher. The lesson was carried out on a biology course for 10 sessions on the topic of the ecosystem and environmental change by the same teacher in three groups.

\section{Participants/Group}

The research subjects (participants) involved three randomly selected groups from two secondary schools. Participants involved in the PBL-CE (A1) group were 56 students, PBL (A2) group were 58 students, and the RL group (A3) were 56 students. The grouping of the students into B1 and B2 was based on the rank of their naturalist intelligence test scores. Group B1 covered $50 \%$ of the students achieving high naturalist intelligence test score and group B2 included 50\% of the students achieving low naturalist intelligence test scores.

\section{Instrument and Procedures}

This study measures two variables that are students' critical thinking skills and. students' critical thinking skills are measured by essay test instruments, and students' curiosity is measured by self-assessment instruments. In this study also developed instruments to measure the natural intelligence, this is used to distinguish participants with high naturalist intelligence and low naturalist intelligence. Therefore, each variable developed its own instrument. The stages of instrument development, namely; 
presentation of conceptual definitions of variables, operational definitions of variables, instrument lines, preparation of instruments, determination of content validity, and testing of instruments to determine internal consistency and instrument reliability.

Determination of the content validity using the Lawshe method. The value of the content validity is indicated by the content validity ratio (CVR) after being validated by six experts. The instrument test was conducted on 40 students who were not research subjects. Based on the test results, the critical thinking skills test instrument consisted of 7 essay items having internal consistency ranging from 0,64 to 0,91 and the instrument reliability of 0,95 . The 7 items students curiosity self-assessment instrument had internal consistency ranging from 0,40 to 0,78 and the instrument reliability of 0,88 . The naturalist intelligence test instrument consisted of 29 items having internal consistency ranging from 0,32 to 0,63 and the instrument reliability of 0,92 .

\section{Data Analysis}

The data on the students' critical thinking skills and curiosity scores were analyzed using descriptive and inferential statistics. The descriptive statistics were used to get a level of students' critical thinking skills and students' curiosity. The inferential statistics Manova was used to test the research hypothesis at the 0,05 significance level.

\section{FINDINGS AND DISCUSSION}

\section{Critical Thinking Skills}

The effect of the treatment of the PBL-CE and naturalist intelligence on critical thinking skills is seen from normalized gain scores (NGs). The comparison of NGs of the students thinking skills in the three groups is presented in Table 1. The average NGs in the PBL-CE group is higher than the PBL and RL groups. The PBL and RL groups have the same category of critical thinking skills, namely low, but the BPL-CE group gets into the moderate category. Based on the data above, it is descriptively known that the critical thinking skills of the students taught with PBL-CE are better than the PBL and RL groups. Table 1 also reveals the comparison between NGs of the students' critical thinking skills with the students' high (B1) and low (B2) naturalist intelligence in group A1, A2, and A3. The average NGs of the students in the A1 group are higher than those in the A2 group in the three treatment groups. The results indicate that the students' critical thinking skills with high naturalist intelligence are better than those with low naturalist intelligence. They also indicate that PBL-CE is able to encourage many students to get a very high and high category in comparison to the teaching and learning using RL. The distribution of the students' abilities in the critical thinking skills aspect based on NGs is presented in Figure 1. 
Table 1

Students critical thinking skills based on NGs in the three groups

\begin{tabular}{lllll}
\hline Groups & Naturalist Intelligence & Mean & Std. Deviation & $\mathrm{N}$ \\
\hline (A1) PBL-CE & (B1) High & 0,4229 & 0,18294 & 28 \\
\cline { 2 - 5 } & (B2) Low & 0,4079 & 0,18685 & 28 \\
\cline { 2 - 5 } & Total A1 & 0,4154 (Category: Moderate) & 0,18337 & 56 \\
\hline (A2) PBL & (B1) High & 0,3514 & 0,19697 & 29 \\
\cline { 2 - 5 } & (B2) Low & 0,2493 & 0,20461 & 29 \\
\cline { 2 - 5 } & Total A2 & 0,3003 (Category: Low) & 0,20561 & 58 \\
\hline (A3) RL & (B1) High & 0,3061 & 0,29494 & 28 \\
\cline { 2 - 5 } & (B2) Low & 0,2757 & 0,24586 & 28 \\
\cline { 2 - 5 } & Total A3 & 0,2909 (Category: Low) & 0,26947 & 56 \\
\hline
\end{tabular}

Figure 1 shows that the students in the PBL-CE group had a greater frequency for the moderate category than those in the PBL and the PR groups. This implies that learning using PBL-CE has a better effect on the students' critical thinking skills.

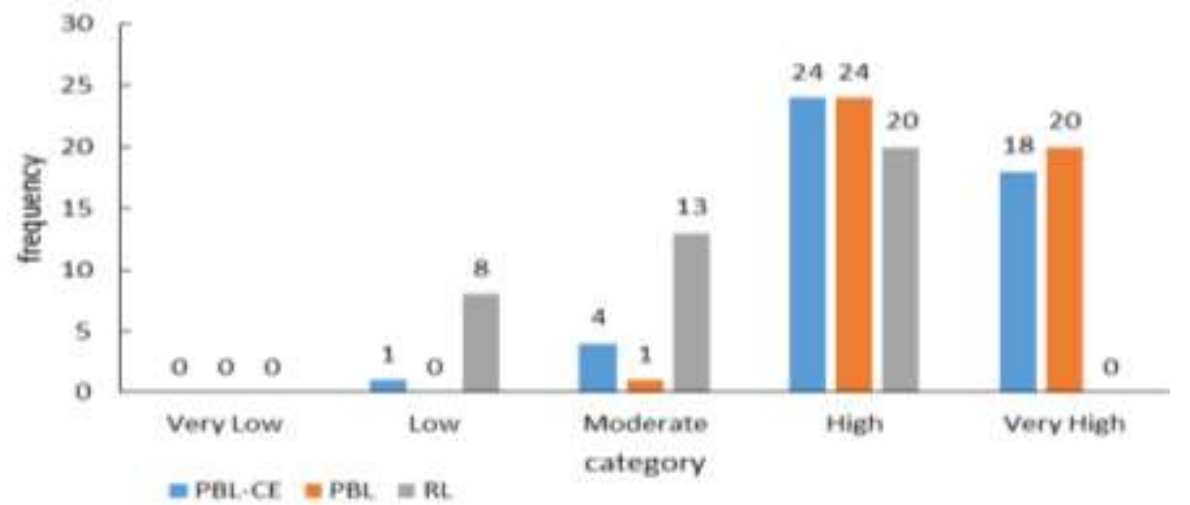

Figure 1

Comparison of the students' frequency based on NGs in each category of the students' critical thinking skills in the three groups.

\section{Students Curiosity}

Measurement of the students' curiosity was carried out after the treatment had been completed. The results of data analysis on the students' curiosity using descriptive statistics are presented in Table 2. It shows that there are differences in the average scores and categories of the students' curiosity in the three groups. The average score of the students' curiosity in the PBL-CE group is higher than those in the PBL and the RL groups. The PBL-CE and the PBL groups have the same category pertaining to curiosity, namely good, but the RL group gets into the lower category, namely fair. Based on the data, it can be descriptively stated that the students' curiosity taught with PBL-CE is better than the PBL and RL groups. 
Table 2

Students curiosity in the three groups

\begin{tabular}{lllll}
\hline Groups & Naturalist Intelligence & Mean & Std. Deviation & $\mathrm{N}$ \\
\hline (A1) PBL-CE & (B1) High & 3,0843 & 0,26599 & 28 \\
\cline { 2 - 5 } & (B2) Low & 3,0596 & 0,27175 & 28 \\
\cline { 2 - 5 } & Total A1 & 3,0320 (Category: Good) & 0,26789 & 56 \\
\hline (A2) PBM & (B1) High & 3,0879 & 0,24972 & 29 \\
\cline { 2 - 5 } & (B2) Low & 3,0269 & 0,38813 & 29 \\
\cline { 2 - 5 } & Total A2 & 3,0574 (Category: Good) & 0,32493 & 58 \\
\hline (A3) RL & (B1) High & 2,9254 & 0,40578 & 28 \\
\cline { 2 - 5 } & (B2) Low & 2,8532 & 0,27356 & 28 \\
\cline { 2 - 5 } & Total A3 & 2,8893 (Category: Fair) & 0,34481 & 56 \\
\hline
\end{tabular}

Table 2 also shows the comparison of the students' curiosity scores with the students with high (B1) and low (B2) naturalist intelligence in A1, A2, and A3 groups. The average score of the students' curiosity for the A1 group was higher than the A2 group in the three groups. The results indicate that the students' curiosity with high naturalist intelligence is better than those with low naturalist intelligence. The PBL-CE is able to encourage many students to get into the very good and the good category in comparison to the learning using the RL. The distribution of the students based on the caring score category is presented in Figure 2.

It is known from figure 2 that the students in the PBL-CE group have a greater frequency for a good category than those in the PBL and PR groups. This indicates that learning with PBL-CE had a better effect on the students' curiosity.

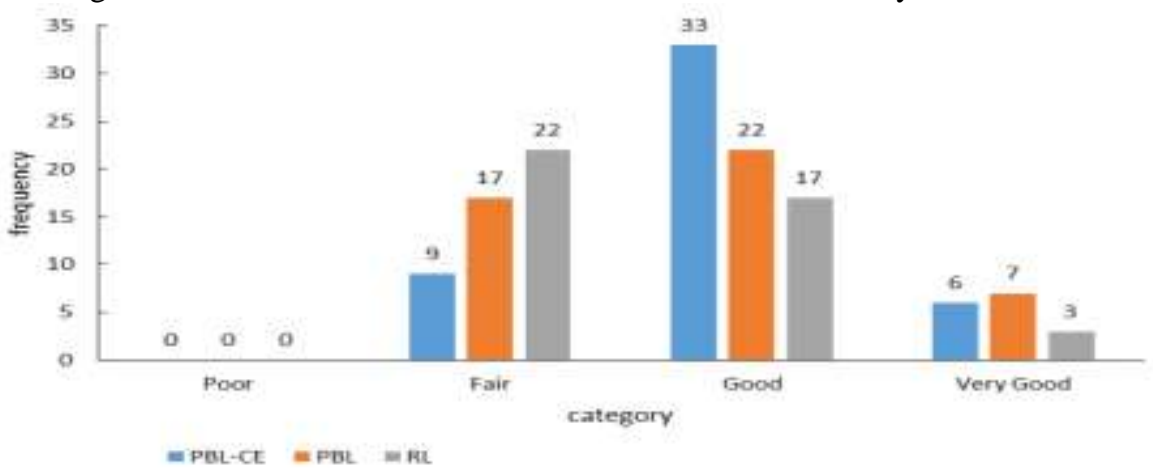

Figure 2

Comparison of the distribution of the students based on the curiosity score category in the three groups.

\section{Hypothesis Testing}

Hypothesis testing of the Manova using SPSS 16.0 was applied to see the main and simple effect at the 0,05 significance level. The results of the analysis are presented in Table 3. 
Table 3

The results of multivariate tests

\begin{tabular}{lll}
\hline Effect & F & Sig. \\
\hline Intercept & 7,600 & 0,000 \\
\hline Groups & 4,822 & 0,001 \\
\hline Naturalist & 1,093 & 0,338 \\
\hline Groups * Naturalist & 0,621 & 0,648 \\
\hline
\end{tabular}

In Table 3, it can be stated that (1) PBL-CE have a significant effect on the students critical thinking skills and curiosity, (2) naturalist intelligence have no significant effect on the students critical thinking skills and curiosity, and (3) The interaction between PBL-CE and naturalist intelligence have no significant effect on the students critical thinking skills and curiosity.

The next analysis is to determine the effect of the PBL-CE variables and naturalist intelligence on each variable of the students' critical thinking and the students' curiosity. The results of the analysis are shown in Table 4 . Table 4 shows that there were significant differences in the average NGs of students' critical thinking skills and the students' curiosity scores between the PBL-CE, the PBL, and the RL groups. Thus, learning using PBL-CE affects students' critical thinking skills and curiosity.

Table 4

Tests of between-subject effects

\begin{tabular}{|c|c|c|c|c|c|c|}
\hline Source & Dependent Var. & Sum of Square & df & Mean Square & $\mathrm{F}$ & Sig. \\
\hline \multirow[t]{2}{*}{ Groups } & ${ }^{\mathrm{a}} \mathrm{CT}$ skills & 0,540 & 2 & 0,270 & 5,479 & 0,005 \\
\hline & ${ }^{\mathrm{b}}$ Curiosity & 0,928 & 2 & 0,464 & 4,658 & 0,011 \\
\hline \multirow[t]{2}{*}{ Naturalist } & ${ }^{\mathrm{a}} \mathrm{CT}$ skills & 0,103 & 1 & 0,103 & 2,081 & 0,151 \\
\hline & ${ }^{\mathrm{b}}$ Curiosity & 0,029 & 1 & 0,029 & 0,287 & 0,593 \\
\hline \multirow{2}{*}{$\begin{array}{l}\text { Groups } \\
\text { Naturalist }\end{array}$} & $*{ }^{*} \mathrm{CT}$ skills & 0,062 & 2 & 0,031 & 0,627 & 0,535 \\
\hline & ${ }^{\mathrm{b}}$ Curiosity & 0,140 & 2 & 0,070 & 0,704 & 0,496 \\
\hline \multirow[t]{2}{*}{ Error } & ${ }^{\mathrm{a}} \mathrm{CT}$ skills & 8,086 & 164 & 0,049 & & \\
\hline & ${ }^{\mathrm{b}}$ Curiosity & 16,335 & 164 & 0,100 & & \\
\hline \multirow[t]{2}{*}{ Total } & ${ }^{\mathrm{a}} \mathrm{CT}$ skills & 27,884 & 170 & & & \\
\hline & ${ }^{\mathrm{b}}$ Curiosity & 1540,959 & 170 & & & \\
\hline \multirow{2}{*}{$\begin{array}{l}\text { Corrected } \\
\text { Total }\end{array}$} & ${ }^{\mathrm{a}} \mathrm{CT}$ skills & 8,793 & 169 & & & \\
\hline & ${ }^{\mathrm{b}}$ Curiosity & 17,432 & 169 & & & \\
\hline
\end{tabular}

$\mathrm{CT}=$ Critical thinking

The post hoc test was conducted to ascertain the group having the best effect toward the variables of the students. The results show that the differences in the average scores of the students critical thinking skills and the students curiosity. The students taught with the PBL-CE obtained the critical thinking average score which is significantly different from the PBL and RL group. PBL-CE treatment is the best treatment to improve 
students' critical thinking skills. Table 5 also shows that the students taught with the PBL-CE obtained higher curiosity average score and it is not significantly different from the PBL group, but they are significantly different from the RL group. However, PBL$\mathrm{CE}$ treatment is the best treatment to improve students' curiosity. The results of the analysis are presented in Table 5.

Table 5

The results of the LSD test

\begin{tabular}{|c|c|c|c|c|c|}
\hline Dependent Variable & (I) Groups & (J) Groups & Mean Diff. (I-J) & Std. Error & Sig. \\
\hline \multirow{6}{*}{$\begin{array}{l}\text { Critical thinking } \\
\text { Skills }\end{array}$} & \multirow[t]{2}{*}{1} & 2 & $0,1150^{*}$ & 0,04160 & 0,006 \\
\hline & & 3 & $0,1245^{*}$ & 0,04196 & 0,003 \\
\hline & \multirow[t]{2}{*}{2} & 1 & $-0,1150^{*}$ & 0,04160 & 0,006 \\
\hline & & 3 & 0,0095 & 0,04160 & 0,821 \\
\hline & \multirow[t]{2}{*}{3} & 1 & $-0,1245^{*}$ & 0,04196 & 0,003 \\
\hline & & 2 & $-0,0095$ & 0,04160 & 0,821 \\
\hline \multirow[t]{6}{*}{ Curiosity } & \multirow[t]{2}{*}{1} & 2 & $-0,0254$ & 0,05913 & 0,667 \\
\hline & & 3 & $0,1427^{*}$ & 0,05964 & 0,018 \\
\hline & \multirow[t]{2}{*}{2} & 1 & 0,0254 & 0,05913 & 0,667 \\
\hline & & 3 & $0,1681^{*}$ & 0,05913 & 0,005 \\
\hline & \multirow[t]{2}{*}{3} & 1 & $-0,1427^{*}$ & 0,05964 & 0,018 \\
\hline & & 2 & $-0,1681^{*}$ & 0,05913 & 0,005 \\
\hline
\end{tabular}

Group 1 = PBL-CE, 2 = PBL, $3=$ RL

*The mean difference is significant at the 0,05 level

The current research produces important findings regarding the effect of PBL-CE and naturalist intelligence on the students' critical thinking skills and curiosity. It showed that there is an effect of PBL-CE on the students' critical thinking skills and curiosity. The PBL-CE treatment is the best treatment to improve students' curiosity than those the PBL and the RL treatments.

During the lesson using the PBL-CE, characters were purposedly designed through the teacher's action at each stage in the learning syntax, including caring character. In several stages of the learning activities, there were always activities of the teacher to generate and strengthen the students' character and remind them to do something related to certain characteristics such as curiosity about the environmental and social problems. In learning using PBL-CE, the students were faced with authentic problems in the environment surrounding them. The students get used to thinking critically when they are confronted with the ones which they often witness every day. The environmental problems the students dealt with were in the form of images and news of electronic media. The images and information from media are very appropriate for students to develop their thinking skills (Sutarto, Indrawati, \& Prihatin, 2018). When PBL-CE was carried out, the students were encouraged to arouse their curiosity about the problems which existed in their environment by learning the problems given. 
The results of the study also showed that there are no effect of naturalist intelligence and the interaction between PBL-CE and naturalist intelligence on the students' critical thinking skills and the students' curiosity. The PBL-CE seemed not to have a significant effect of activating the students' critical thinking skills and curiosity as it was paired with the students' naturalist intelligence. The PBL-CE and PBL did not only support the critical thinking skills and curiosity of the students with high naturalist intelligence, but also those with low naturalist intelligence. This condition was affected by PBL-CE and PBL which required both individuals and groups to participate actively in the activity of problem analysis, convey ideas, find the right information for solving the problem, build hypothesis, think about how the problem-solving works, and set up logic about the relationship between one fact with another. The students with high and low naturalist intelligence can respond well to the learning activities carried out using PBL-CE, PBL, and RL. According to Witte and Rogge (2016), the students in the PBL are sometimes not better than those in the traditional class in terms of knowledge acquisition or problem-solving skills.

One of the new findings in this study is that the problem-based learning with character emphasis treatment is able to encourage many students to get the higher categories of critical thinking skills and curiosity than those problem-based learning and regular learning treatments. The existing research only reveals the influence of PBL on students' critical thinking. The learning using PBL-CE gives the students a challenge in order that they can interact and solve the environmental problem given. Students ask closed questions and open questions about the environmental problems presented by the teacher. According to Almulla (2018) students who frequently ask open questions have better critical thinking skills. The completion of a problem requires analytical and critical thinking skills, analysis of possible solutions, evaluation of the problems and available solutions, and ability to design something as problem solving alternatives. These abilities need to be continually strengthened in the learning using PBL-CE, although the students taking part in it having high or low naturalist intelligence. It is different from the learning process using the regular learning which tends to place the students as the learning object. This has caused a decline in the ability of the students to analyze, evaluate, and create, and weaken the students' character in the learning. According to Aldarmahi (2016), in the PBL, the students are capable of integrating basic science with life problems in comparison to those in the conventional system.

\section{CONCLUSION}

PBL-CE has a significant effect on the students' critical thinking skills and students' curiosity. It supports the students to get higher categories of critical thinking skills and curiosity. It is the best treatment to improve students' critical thinking skills and students' curiosity. Naturalist intelligence does not have a significant effect on the students' critical thinking skills and students' curiosity. The interaction between PBL-CE and naturalist intelligence does not affect the students' critical thinking skills and students' curiosity. The students with high and low naturalist intelligence give the same response to the PBL-CE, the PBL, and the RL. The character can be implemented explicitly, in detail, and operational in PBL. PBL syntax can be enriched with activities that 
encourage students' critical thinking skills and express students' curiosity during learning. The teachers are required to be creative in developing learning resources needed in the learning process, such as student worksheets, tools and materials needed in the process of solving, problem, and assessment instruments for critical thinking skills and student curiosity that are valid and reliable.

The limitation of this study is that it only measures the aspects of critical thinking and curiosity, whereas on the one hand character emphasis and naturalist intelligence are closely related to environmental attitudes. In addition, learning is carried out in biology courses on the topic of ecosystem and environmental change by the same teacher in three groups. Limited topics might influence the generalization of findings, and three classes taught by the same teacher can be bored and may affect the findings. To overcome these limitations, this study recommends several things that can be considered for further studies. First, further research can explore the effects of implementing the model conditioned in this study on environmental attitudes, and can also measure other variables such as learning motivation. Second, learning is carried out in biology courses with topics expanded with different teachers in each school or class. However, with a number of limitations, the findings in this study become important as a basis for further research.

\section{REFERENCES}

Aldarmahi, A. (2016). The impact of problem based learning versus conventional education on students in the aspect of clinical reasoning and problem solving. Education in Medicine Journal, 8(3), 1-10.

Almulla, M. (2018). Investigating teachers' perceptions of their own practices to improve students' critical thinking in secondary schools in Saudi Arabia. International Journal of Cognitive Research in Science, Engineering and Education (IJCRSEE), 6(3), 15-27.

Anazifa, R. \& Djukri. (2017). Project-based learning and problem- based learning: Are they effective to improve students' thinking skills. Jurnal Pendidikan IPA Indonesia, $6(2), 346-355$.

Arnone, M. P., Small, R. V, Chauncey, S. A., \& Mckenna, H. P. (2011). Curiosity, interest and engagement in technology-pervasive learning environments: A new research agenda Marilyn. Education Tech Research Dev, 181-198. https://doi.org/10.1007/s11423-011-9190-9

Barbiero, G. \& Berto, R. (2018). From biophilia to naturalist intelligence passing through perceived restorativeness and connection to nature. Annals of revews and research, 3(1), 12-17.

BSNP. (2010). Paradigma Pendidikan Nasional Abad XXI. Versi 1.O. Jakarta. [in Indonesia]

Callina, K. S., Burkhard, B., Schaefer, H. S., Powers, J., Murray, E. D., Kobylski, G., Ryan, D. M., Kelly, D., Matthews, M. D., \& Lerner, R. M. (2018). Character in context: 
Character structure among United States Military Academy cadets. Journal of Moral Education, 48(4), 1-26.

Cassady, J. C., Kozlowski, A., \& Kornmann, M. (2008). Electronic field trips as interactive learning events: promoting student learning at a distance. Journal of Interactive Learning Research, 19(3), 439-454.

Ciptasari, D., Nuswowati, M., \& Sumarni, W. (2015). Pembelajaran zat adiktif dan psikotropika berpendekatan contextual teaching and learning. Unnes Science Education Journal, 4(1), 756-762.

Delaney, Y., Pattinson, B., Mccarthy, J., \& Beecham, S. (2017). Transitioning from traditional to problem-based learning in management education: The case of a frontline manager skills development programme. Innovatıons in Educatıon and Teaching International, 54(3), 214-222.

Dinkha, J. (2008). Effects of character education on the self-esteem of intellectually able and less able elementary students in Kuwait. International Journal of Special Education, 5(4), 47-59.

Duran, M., \& Dökme, I. (2016). The effect of the inquiry-based learning approach on student's critical-thinking skills. Eurasia Journal of Mathematics, Science and Technology Education, 12(12), 2887-2908.

Eichmann, B., Goldhammer, F., Greiff, S., Pucite, L., \& Naumann, J. (2019). The role of planning in complex problem solving. Computers and Education, 128, 1-12.

Ertmer, P. A., Schlosser, S., Clase, K., \& Adedokun, O. (2014). The grand challenge: Helping teachers learn/teach cutting-edge science via a PBL approach. Interdisciplinary Journal of Problem Based Learning, 8(1), 2-20.

Gardener, H. E. (1999). Intelligence reframed: Multiple intelligences for the 21st century. Basic Books, New York.

Gulten, D. C., Yaman, Y., Deringol, Y., \& Ozsari, I. (2011). The relationship between curiosity level and computer self efficacy beliefs of mathematics, science, social sciences and elementary teachers candidates. The Turkish Online Journal of Educational Technology, 10(4), 11-13

Handoyo, S. S., Iriani, T., \& Septiandini, E. (2019). Study of the analysis on the characteristics of learning style of the students of the vocational education of building construction study program, Faculty of Engineering, Jakarta State University. 3rd UNJ International Conference on Technical and Vocational Education and Training, 339348.

Hasanah, N., Harmawati, D., Riyana, M. \& Usman, A. N. (2019). Improve naturalist intelligence of early childhood through gardening activities in group children a Merauke State Pembina Kindergarten. IOP Conf. Ser.: Earth Environ. Sci. 343, 1-7 
Hasanpour, Bagheri, M., \& Heidari, F. G. (2018). The relationship between emotional intelligence and critical thinking skills in Iranian nursing students. Medical Journal of the Islamic Republic of Iran (MJIRI), 2018, 1-5

Hayes, M. A. (2009). Into the field: Naturalistic education and the future of conservation. Conservation Biology, 23(5), 1075-1079.

Hofstein, A., Nahum T. L., \& Shore R. (2001). Assessment of the learning environment of inquiry-type laboratories in high school chemistry. Learning Environments Research, 4(3), 193-207.

Isdaryanti, R., Sukestiyarno, \& Florentinus, W. (2018). Teachers' performance in science learning management integrated with character education. Jurnal Pendidikan IPA Indonesia, 7(1), 9-15.

Kaczmarek, L. D., Baczkowski, B., Enko, J., Baran, B., \& Theuns, P. (2014). Subjective well-being as a mediator for curiosity and depression. Polish Psychological Bulletin, 45(2), 200-204.

Khasani, R., Ridho, S., \& Subali, B. (2019). Identifikasi Kemampuan Berpikir Kritis Siswa SMP Pada Materi Hukum Newton. Jurnal Penelitian Pendidikan IPA, 5(2), 165.

Latifa, B. R. A., Verawati, N. N. S. P., \& Harjono, A. (2017). Pengaruh model learning cycle 5 e (engage, explore, explain, elaboration, \& evaluate) terhadap kemampuan berpikir kritis peserta didik kelas X MAN 1 Mataram. Jurnal Pendidikan Fisika dan Teknologi, 3(1), 61-67.

Mak, W. S. (2014). Evaluation of a moral and character education group for primary school students. Discovery-SS Student E-Journal, 3, 142-164.

Mapeala, R., \& Siew, N. M. (2015). The development and validation of a test of science critical thinking for fifth graders. SpringerPlus, 4(1), 1-13.

Miri, B., Ben-Chaim, D., \& Zoller, U. (2007). Purposely teaching for the promotion of higher-order thinking skills: A case of critical thinking. Research in Science Education, 37(4), 353-369.

Mouhtarim, S. E. (2018). Integrating critical thinking skills in reading courses at the university level: The case of faculty of letters and humanities, Beni-Mellal, Morocco. Arab World English Journal, 9(3), 331-344.

Muliastuti, L. (2017). Panduan Penilaian Penguatan Pendidikan Karakter. Jakarta: Pusat Analisis dan Sinkronisasi Kebijakan, Sekjen Kemendikbud.

Mutakinati, L., \& Anwari, I. (2018). Analysis of students' critical thinking skill of middle school through STEM education project-based learning. Jurnal Pendidikan IPA Indonesia, 7(1), 54-65.

Nasution, D., Harahap, P. S., \& Harahap, M. (2018). Development instrument's learning of physics through scientific inquiry model based Batak culture to improve science process skill and student's curiosity. Journal of Physics: Conference Series, 970(1). 
Oktay, A., \& Safak, U. (2012). Science and technology teacher candidates' problem solving skills. Journal of Turkish Science Education, 9(2), 82-94.

Osman. (2010). Virtual tutoring: An online environment for scaffolding students' metacognitive problem solving expertise. Journal of Turkish Science Education, 7(4), $3-13$

Özgenel, M. (2018). Modeling the relationships between school administrators' creative and critical thinking dispositions with decision making styles and problem solving skills. Educational Sciences: Theory \& Practice, 1, 673-700.

Patel, C., Lei, Y., Liu, L., Vernica, R., Fan, J., Short, B., Liu, J., \& Simske, S. J. (2017). Learning in the 21 st century cyber-physical age. APSIPA Transactions on Signal and Information Processing, 6(12), 1-14.

Prayogi, S., Yuanita, L. \& Wasis. (2017). Critical-Inquiry-Based-Learning: Model of learning to promote critical thinking ability of pre-service teachers. Journal of Physics: Conference Series 947: 1-6, doi:10.1088/1742-6596/947/1/012013

Prayogi, S., Yuanita, L., \& Wasis. (2018). Critical inquiry based learning: A model of learning to promote critical thinking among prospective teachers of physic. Journal of Turkish Science Education, 15(1), 43-56.

Prayogi, S., Muhali, Yuliyanti, S., Asy’ari, M., Azmi, I., \& Verawati, N. N. S. P. (2019). The effect of presenting anomalous data on improving student's critical thinking ability. International Journal of Emerging Technologies in Learning, 14(6), 133-137.

Qing, Z., Jing, G., \& Yan. W. (2010). Promoting preservice teachers' critical thinking skills by inquiry-based chemical experiment. Procedia Social and Behavioral Sciences, 2, 4597-4603

Rehmat, A. P., \& Bailey, J. M. (2014). Technology integration in a science classroom: Preservice teachers' perceptions. J Sci Educ Technol, 23, 744-755.

Ritter, S. M., \& Mostert, N. (2016). Enhancement of creative thinking skills using a cognitive-based creativity training. Journal of Cognitive Enhancement, 1(3), 243-253.

Rohmah, L. I. (2016). Peningkatan kecerdasan naturalis melalui bermain messy play terhadap anak usia 5 - 6 tahun. Jurnal Pedagogi, 5(1), 47-52.

Roos, A. R. H. (2017). Naturalistic intelligence. International Montessori Schools and Child Development Centres Brussels, Belgium

Schwab, K. (2016). The Fourth Industrial Revolution. Route de la Capite CH-1223 Cologny/Geneva Switzerland: World Economic Forum.

Skobelev \& Borovik, Y. (2017). On the way from industry 4.0 to industry 5.0. International Scientific Journal “Industry 4.0, ” 311(6), 307-311

Susilawati, S., Jamaluddin, J., \& Bachtiar, I. (2018). Pengaruh model pembelajaran berbasis masalah $(\mathrm{PBM})$ berbantuan multimedia terhadap kemampuan berpikir kritis 
peserta didik kelas VII SMP Negeri 2 Mataram ditinjau dari kemampuan akademik. Jurnal Pijar MIPA, 12(2), 64-70.

Sutarto, Indrawati, J. Prihatin, P. A. D. (2018). Geometrical optics process image-based worksheets for enhancing students' higher-order thinking skills and self-regulated learning. Jurnal Pendidikan IPA Indonesia, 7(4), 376-382.

Tiruneh, D. T., De Cock, M., \& Elen, J. (2018). Designing learning environments for critical thinking: Examining effective instructional approaches. International Journal of Science and Mathematics Education, 16(6), 1065-1089.

Tsai, C., \& Chiang, Y. (2013). Research trends in problem-based learning (PBL) research in e-learning and online education environments: A review of publications in SSCI-indexed journals from 2004 to 2012. British Journal of Educational Technology, 44(6), 185-191.

Verawati, N.N.S.P., Hikmawati \& Prayogi, S. (2019a). Conceptual framework of reflective-inquiry learning model to promote critical thinking ability of preservice physics teachers. Journal of Physics: Conference Series 1397, 1-10.

Verawati, N.N.S.P., Prayogi, S., Gummah, S., Muliadi, A. \& Yusup, M.Y. (2019b). The effect of conflict-cognitive strategy in inquiry learning towards pre-service teachers' critical thinking ability. Jurnal Pendidikan IPA Indonesia, 8(4), 529-537.

Wahyudi, Verawati, N.N.S.P., Ayub, S., \& Prayogi, S. (2018). Development of inquirycreative-process learning model to promote critical thinking ability of physics prospective teachers. Journal of Physics: Conference Series 1108, 1-6. doi: 10.1088/1742-6596/1108/1/012005

Wahyudi, Verawati, N. N. S. P., Ayub, S., \& Prayogi, S. (2019a). The effect of scientific creativity in inquiry learning to promote critical thinking ability of prospective teachers. International Journal of Emerging Technologies in Learning, 14(14), 122131.

Wahyudi, Verawati, N.N.S.P., Ayub, S., \& Prayogi, S. (2019b). Effectiveness of Inquiry-Creative-Process Learning Model to Promote Critical Thinking Ability of Prospective Physics Teachers. Journal of Physics: Conference Series 1417, 1-6.

Walter, C. and, \& Walter, P. (2018). Is critical thinking a mediator variable of student performance in school? Educational Research Quarterly, 41(3), 3-24.

Weible, J. L., \& Zimmerman, H. T. (2016). Science curiosity in learning environments: Developing an attitudinal scale for research in schools, homes, museums, and the community. International Journal of Science Education, 38(8), 1235-1255.

Witte, K. D, \& Rogge, N. (2016). Problem-based learning in secondary education: Evaluation by an experiment. Education Economics, 24(1), 58-82

Yao, X., Yuan, S., Yang, W., Chen, Q., Wei, D., Hou, Y. Zhang, L. Qiu, J., \& Yang, D. (2018). Emotional intelligence moderates the relationship between regional gray matter volume in the bilateral temporal pole and critical thinking disposition. Brain Imaging and Behavior, 12(3), 488-498. 